
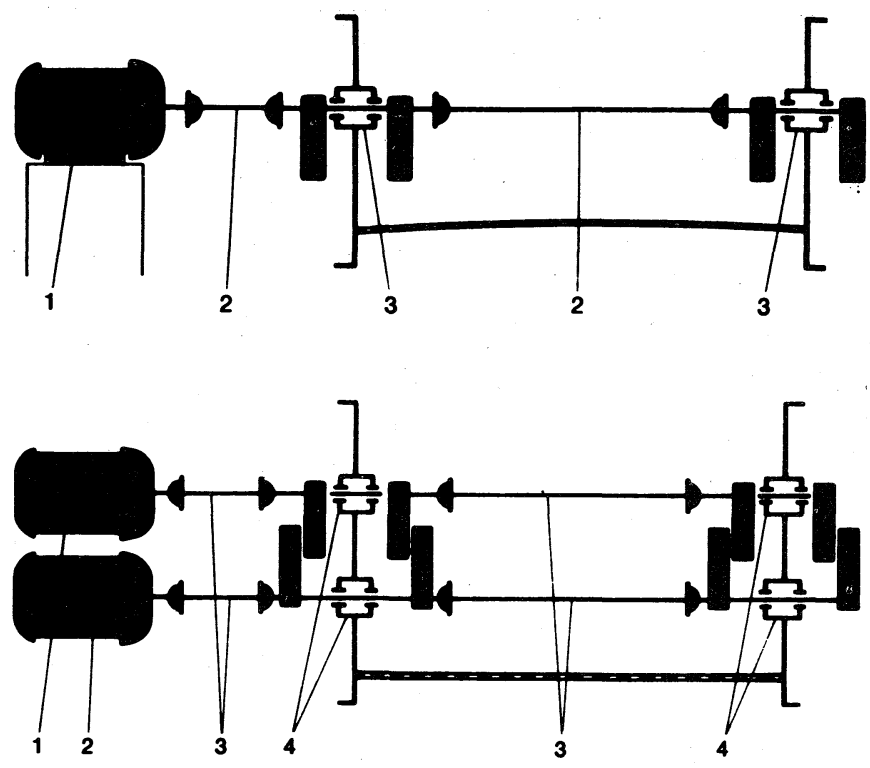

第 5 図 大型振動ふるいの発振機構

の両側に配置し, しかもべアリングの至近距離に取付けることに よつて駆動軸のひず゙みをできる限り小さくしている。

e. 二軸直線振動型振動ふるいについて，おのおのの駆動軸に 別々の電動機を直結し二軸間を結ぶタイミングギヤ一またはタイ
ミングベルトを除いている。これは慣性の原理によつて必要 ない。

f. 駆動軸はニニバーサルジョイントによつて連結されて いるが，それを分断することによつてベアリング交換に必要 なスペースを節約できる。このことはこのふるい機を並列に， その間隔を最小にして何台でも設置できることになる。

\section{4. おわりに}

KHD Humboldt Wedag AG は, ほとえどあらゆる種類 の選炭関連機械を製作しているが，第27回全国選炭大会にお いて好評を得た当社の新型スラリーポンプROPUも日本での 国産の準備も整い間もなく発売される予定である。

選炭工場は通常湿式工程であるため各所で固液分離機が必 要であるが, 特にジグ水洗の粉精炭, 浮選精炭および浮選テ ーリング等の脱水用として，大容量で高効率の分離機が各用 途に応じて各種のものが開発されている。これらについては 是非次回に紹介したい。

本稿に関する質問，意見等賜われば幸甚である。

$$
\text { 文献 }
$$

1) Brinkmann, F. : World Coal Vol.3, No.5/May 1977 2) Zimmerman, R.E.: World Coal Vo1.3, No.10/October 1977

3) Wilczynski, P. : Aufberei tungs - Technik, Jahrgang 16 (1975) Heft 6 , Seite $275-281$

4) Becker, M.: Glückauf, Jahrgang 115•1, Februar 1979, $\mathrm{Nr} .3$

〔新技術紹介〕

（14）石炭貨車の融炭設備開発研究

\section{1. まえがき}

北海道における石炭凍結貨車の荷卸し作業について, 冬期間に は山元から埠頭までの貨車輸送中（継送のため途中駅に留置され る場合も含む）および, 埠頭にての荷卸しまでの間に貨車内の石 炭が凍結し, 特に貨車底部では $20 \sim 30 \mathrm{~cm}$ におよぶ厚い凍結層 ができ，この荷卸しには多くの人員と時間を費いやしている。

この凍結貨車の荷卸し作業について，国鉄や業者が昔から種々 の対策を考えたが，実効のあるものがなかつた。

対策の内容は

1. 不凍液の使用

2. 底開放扉から電気オーガにより孔をあけ, 下から徐々に孔 を大きくして上から突き落す方法

3. 貨車内面にあらかじめ岩粉を吹きつけておく方法

4. 底の山形部にゴムをはりつける

5. ピック, 融炭室の利用

等であつたが, それぞれに問題があり, 荷卸作業は下記のように 変移してきた。

（1）貨車ゲートを開いて人力で金棒（先端がヤスリ状または, ヘラ状のもの）にて底部に孔をあけ, さらに金棒とッルハシを使 つて孔の周囲を拡大するように切崩して荷卸し作業がおこなわれ た(第 1 図)。

この場合, 従事する労働者は豊富な経験と重労働に耐える体力 を必要とし,この条件にマッチした労働者でも, 1 車当り 6 人で
$0.5 \sim 2$ 時間の作業時間を要し, 厳冬期には 1 日 1 人当り荷卸し 車数は平均 2 車程度にすぎなかつた。

（2）特に 1 車当り 2 時間を要するものは, 金棒や,ッルハシを 使つての人力のみでは能率も悪く到着車数を消化できず，空気圧 縮機でュールピックを使いさく孔，破碎する方法を併用した。

苫小牧港において，1 日当り 300 350 車の貨車到着があるが， 前項の方法では完全に消化できず，又年々経験ある重労働者の求 人が困難となるばかりで, 抜本的な荷卸し作業方法の開発が要求 されてきた。

\section{2. 瀜炭開発試案について}

ここで試案されたのが蒸気による凍結炭融解であり, 数年間の 研究の結果, 昭和 43 年 12 月に設置された $4 \mathrm{t}$ のボイラによつて 発生した蒸気圧力 $7 \mathrm{~kg} / \mathrm{cm}^{2}$, 温度 $170{ }^{\circ} \mathrm{C}$ の高圧蒸気を使用して, 1 車当り 3 本の噴射ノズルを貨車内に挿入，約 1 時間経過すると 凍結炭は融解し，夏期とほぼ同一の時間で荷卸しが終了すること が確認された。

しかし 1 日当り $300 〜 350$ 車 を消化するためには， 1 列車15両 を 1 サイクル30分で処理しなければならないことから，4tボイ ラではノズル (噴射口径 $7 \mathrm{~mm}$ ) が 20 本限度の害績から勘案して, $4 \mathrm{t} \times(60$ 本 $\div 20$ 本 $)=12 \mathrm{t}$ 容量のボイラが必要と考光, 昭和 45 年 12 月 $8 \mathrm{t}$ ボイラ 1 基を増設, 1 車当り㨀入ノズルも 4 本とし現 在に至つている(第2図)。 

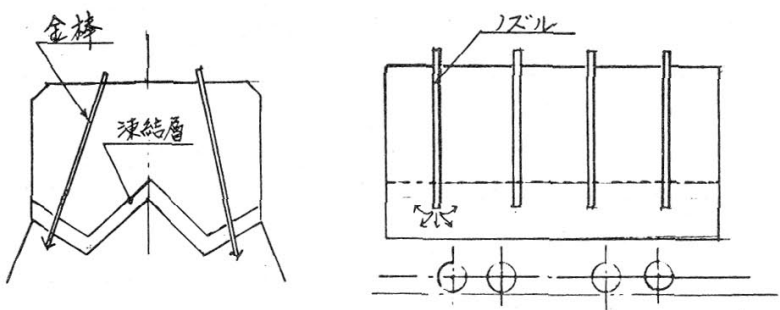

第 1 図

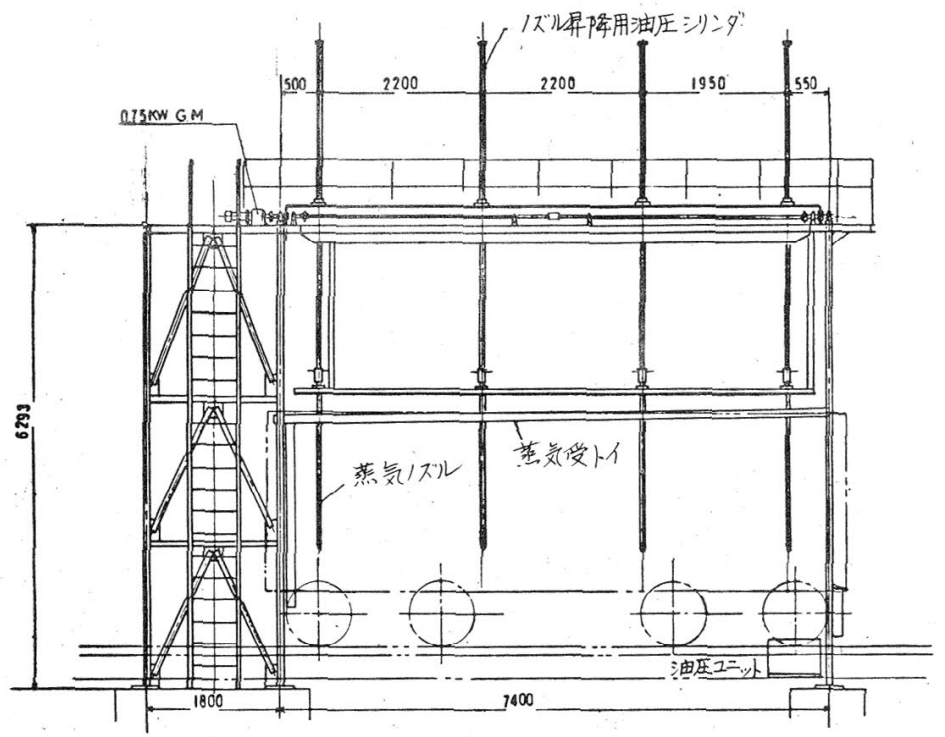

節 3 图正面図

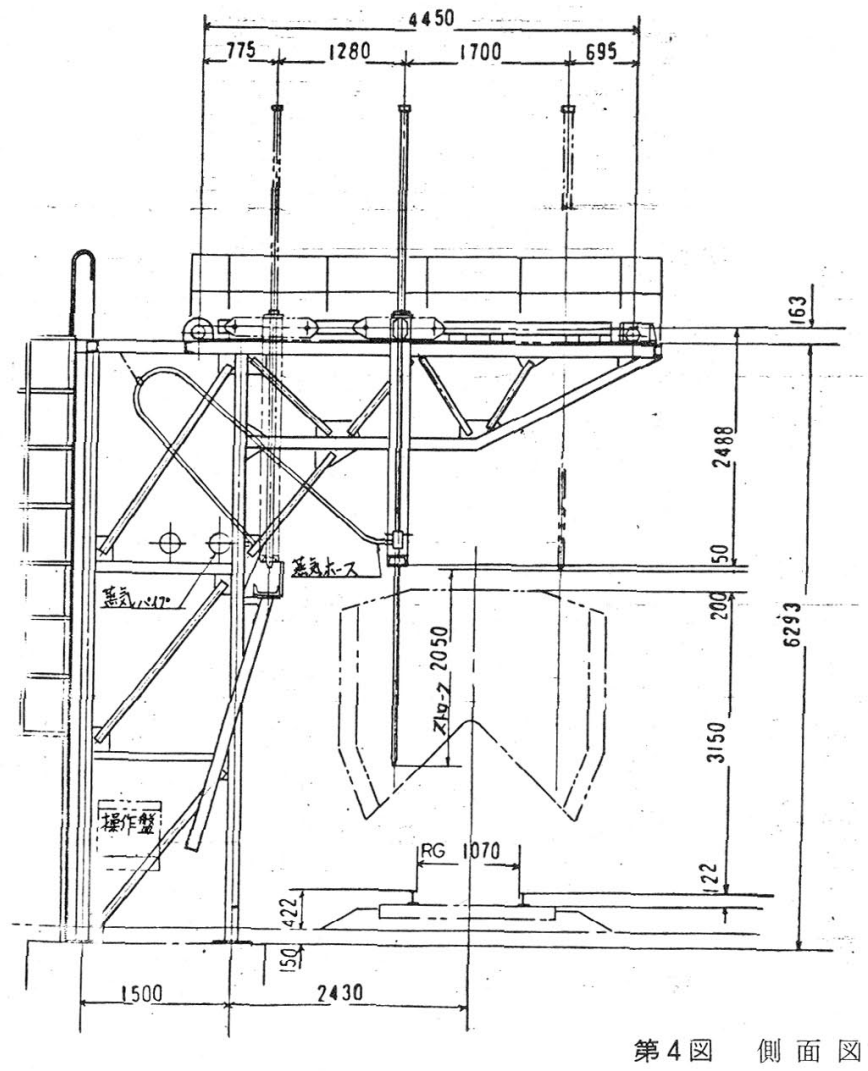

\section{3. 融炭設備の機械化}

現在ノズル挿入作業は，1回の押上げ車数15両に対して14名の 作業者が担当しているが，高温高圧蒸気の噴射ノズルを操作する 危険性と凍結融解状況を判断する経験者求人困難性からこれを機 械化し，人員の減少と時間の短縮により融炭経費の節減を困るこ とを目的とするものである。すなわちノズル捜入作業を機械化す ることによつて, 操作盤の運転工 1 名各ユニット（ 5 車で1ユ ット虽成し計 3 ニニット)に各 1 名配置の計 4 名で作業が可能 であることから， 1 方では $14-4=10$ 名，2方にて 合計 20 名の減員となる。

\section{4. 試験実施の場所}

苫小牧港埠頭（苫小牧開発(株) 中野駅構内）で, 既設融炭設備の最東端の貨車 1 車分に 1 基併置する。

\section{5. 試 験 項 目}

1. 噴射ノズルの挿入，引技きおよび移動機構の 試用による可否の確認

（1）噴射ノズルの㨀入，引抜きおよび移動の時間 が人力作業に比較して時間短縮の可否

（2）噴射ノズル移動が積載の石炭に支障のない構 造の可否

(3) 噴射蒸気の量の調節機構の可否

(4) 保温用の蒸気がディーゼル運転士, 操車係, 融炭作業者に支障なく処埋の可否

2. 各部機構の凍結上の問題点

(1) 各配管,バルブ等の凍結有無

（2）ノズル移動装置のチェンの凝結蒸気による凍 結の有無

3. 省力効果の確認

(1) ノズルの位置が一定のため, 貨車内部の凍結状況に より任意扦入の変更ができないが，人Jの場合希望する位 置に插入可能である。その差異

（2）ノズル長さが適当かどうか，南北両端のリミットス イッチ位置の関倸

以上これらを試験車と比較車 (同一炭種，同一山元日時) とを同一条件で融解させて省力効果を確認する。

\section{6. 試験研究期間}

昭和 53 年 8 月から昭和 54 年 3 月まで。

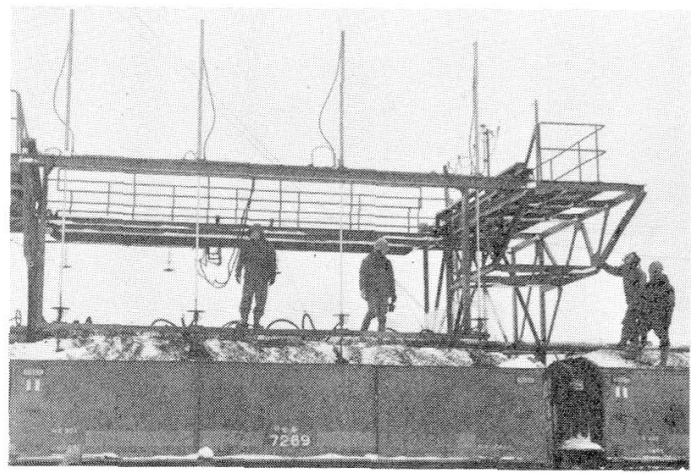

日本鉱業会誌/951099 ('79-9) $671<39\rangle$ 
7. 試験用機構組立図(第 3 図，第 4 図参照)

\section{8. 動作説明（第 5 図参照）}

(1)〔A)は通常停止位置を示す。

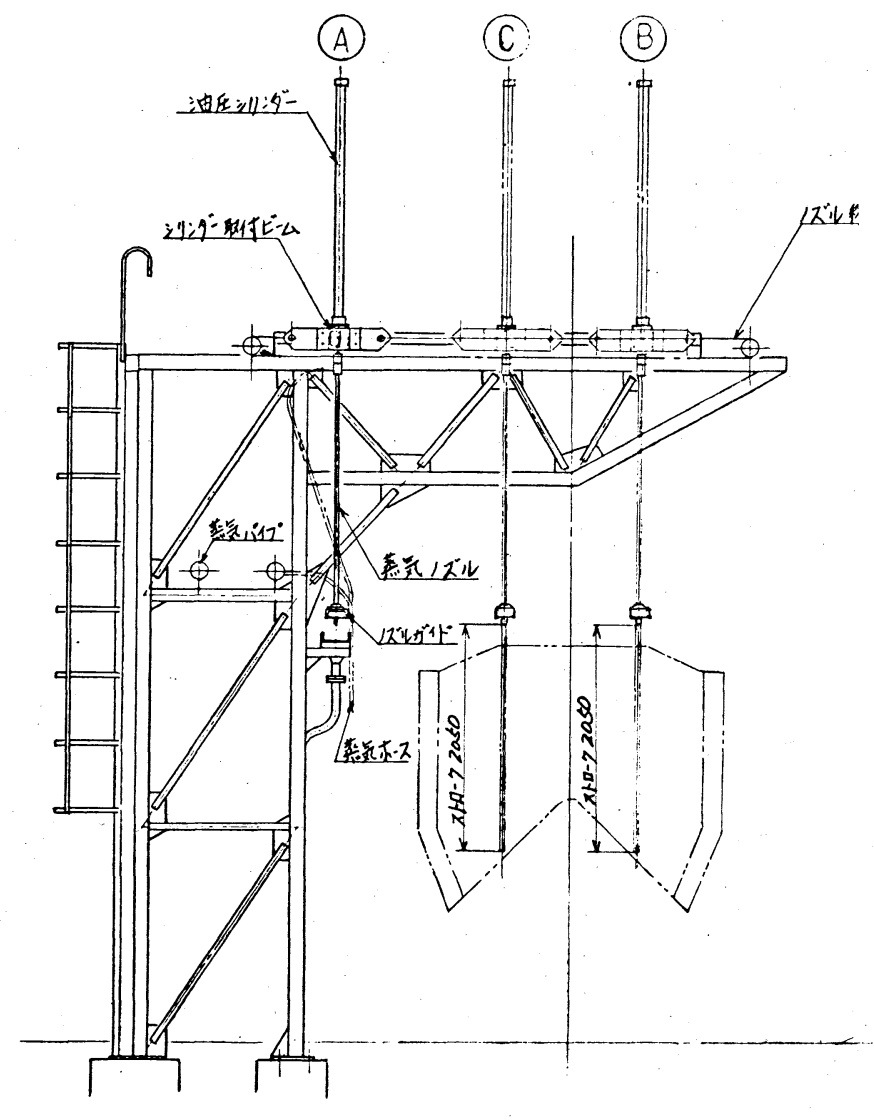

第 5 図
（2）始動押釦スイッチを動作させると，ノズルに取付けられ たビームが移動し, 北側に設けたリミットにより(B)点に自動停止 する。

(3) 油圧シリンダ下降用スイッチにより，ノズルは石炭貨車底 面に向つて押し込まれ，2050 mmのストロークエンドにて停止す る。

（4） B点にて融炭完了後, シリンダを上昇させ(C)点に移 動させリミットスイッチにて自動停止する。

(5) (3) と同様の動作を行ない(C)点における融炭完了後,

(A)点に移動させる。

\section{9. 動作時の蒸気の吹出し状態}

常時蒸気は電磁弁により閉じられ，ノズル挿入後蒸気操 作用スイッチを開に選択すると電磁弁が開き吹出蒸気は全 開になり，閉に選択すると蒸気は止まる。

蒸気操作用スイッチを自動にセットした場合, ノズル下 降開始および上昇完了後自動的に電磁弁の開閉がおこなう ことができる構造になつている。

なおノズルおよび配管部品の倲結防止のため, バイパス 回路を設け保温蒸気が常時吹出している。

\section{0. 試験研究結果表 ( 第 1 表参照 ) \\ 11. 実験における重点的考察}

前項にのべた試験項目をさらに絞り, 次の 4 点について 考察した。

1. 留置期間が長く, しかも最低温度が継続した場合， ノズル挿入が可能かどうか。

2. 荷卸し時において貨車の開放部個所の凍結炭層がど のような状態になつているか。

3. 人力と機械とでの融炭のための挿入時間の差につい $\tau$

4. 保温中の各配管部品の凍結状態について

以上 4 点について次のような結果を得た。

1.についてはノズル插入にトラブルがなく挿入可能である。

第1表 特定結果のみ記載

\begin{tabular}{|c|c|c|c|c|c|c|c|c|c|c|c|c|}
\hline 山発 & $\begin{array}{l}\text { 到着 } \\
\text { 日時 }\end{array}$ & \begin{tabular}{r|r|} 
留明 \\
\end{tabular} & 置期 & $\frac{1 \text { 间最 }}{138 \text { 目 }}$ & 僬湿 & 度 & \begin{tabular}{|l} 
荷第 \\
日時
\end{tabular} & 岸種 & $\begin{array}{l}\text { 华車 } \\
\text { 番亭 }\end{array}$ & 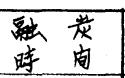 & $\begin{array}{l}\text { 荷却 } \\
\text { 時周 }\end{array}$ & 摘 \\
\hline $1 / 24$ & $0^{30 h}$ & $\begin{array}{l}1 / 4 \\
-111^{\circ} \mathrm{C}\end{array}$ & & & & & $1 / 25$ & 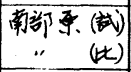 & $\begin{array}{l}3337 \\
6910\end{array}$ & $\begin{array}{cc}10^{\min } \\
8^{-1}\end{array}$ & $\begin{array}{l}10^{\mathrm{min}} \\
10\end{array}$ & 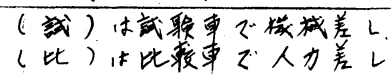 \\
\hline $1 / 24$ & $\frac{1 / 25}{17^{26}}$ & $\begin{array}{l}1 / 24 \\
-11\end{array}$ & $\begin{array}{l}1 / 25 \\
-10\end{array}$ & & & & 20.00 & 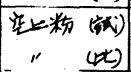 & $\begin{array}{l}4053 \\
2063\end{array}$ & $\begin{array}{l}15 \\
\text { 北 } 10\end{array}$ & $\begin{array}{l}12 \\
10\end{array}$ & 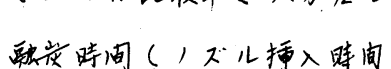 \\
\hline $1 / 25$ & $1 / 27,26$ & \begin{tabular}{|c|}
$/ 25$ \\
-10 \\
\end{tabular} & $\begin{array}{r}16 \\
-7\end{array}$ & $1 / 27$ & & & 21.00 & \begin{tabular}{|c|} 
空上粉 \\
1 (彭) \\
\end{tabular} & 4573 & $\begin{array}{ll}\text { 背 } 15 \\
\text { 南 } 15 \\
\end{array}$ & 8 & 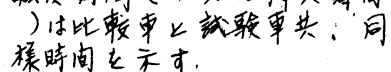 \\
\hline $1 / 26$ & $1 / 30$ & $\begin{array}{c}1 / 26 \\
-7\end{array}$ & $\begin{array}{c}1 / 37 \\
-11\end{array}$ & -14 & $\begin{array}{c}1 / 9 \\
-14\end{array}$ & \begin{tabular}{|l|l}
$1 / 30$ \\
-14
\end{tabular} & {$\left[\begin{array}{ll}3 / 31 \\
2,20\end{array}\right.$} & 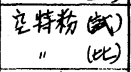 & 4289 & $\begin{array}{ll}\text { 比 } & 15 \\
1 & \text { 南 } \\
15\end{array}$ & $\begin{array}{l}30 \\
26\end{array}$ & 问の上段は試段事 \\
\hline $2 / 2$ & $2 / 299^{50}$ & $3 / 2$ & & & & & $3 / 3$ & \begin{tabular}{|r|} 
复特粉(試) \\
$n \quad($ 比 $)$ \\
\end{tabular} & $\begin{array}{l}-5015 \\
8057 \\
5015\end{array}$ & $\begin{array}{ll}\text { 让 } & 10 \\
\text { 南 } & 8\end{array}$ & 2 & 下纹は比较审を示す。 \\
\hline $1 / 31$ & $\begin{array}{ll}3 / 4 & \\
& 0.08 \\
& 0.0\end{array}$ & $\begin{array}{c}1 / 31 \\
-7 \\
\end{array}$ & $\begin{array}{l}2 / 1 \\
-2 \\
\end{array}$ & \begin{tabular}{|l}
$2 / 2$ \\
-3
\end{tabular} & $\begin{array}{l}2 / 3 \\
-2\end{array}$ & $2 / 4$ & $3 / 4$ & 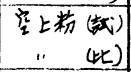 & $\begin{array}{l}3814 \\
3504\end{array}$ & $\begin{array}{ll} & 15 \\
\text { 南 } & 12\end{array}$ & 19 & \\
\hline $3 / 6$ & $3 / 9$ & \begin{tabular}{|l|l|}
$2 / 6$ \\
-11
\end{tabular} & $\begin{array}{l}2 / 7 \\
-5\end{array}$ & $\begin{array}{c}3 / 8 \\
-18\end{array}$ & $\begin{array}{c}399 \\
12 \\
\end{array}$ & & $111^{15}$ & 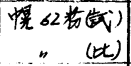 & 6788 & $\begin{array}{ll}\text { 北 } & 15 \\
\text { 南 } & \% 5\end{array}$ & $\begin{array}{l}30 \\
20\end{array}$ & \\
\hline 38 & $\begin{array}{rr}2 / 11 & \\
& 0,08 \\
\end{array}$ & $\begin{array}{c}36 \\
-18\end{array}$ & $\begin{array}{c}2 / 4 \\
-12 \\
\end{array}$ & $\begin{array}{l}3 / 0 \\
-3\end{array}$ & $\begin{array}{c}2 / 11 \\
-3\end{array}$ & & $2 / 118^{20}$ & 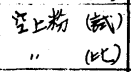 & $\begin{array}{l}4079 \\
4559\end{array}$ & $\begin{array}{ll}\text { 北 } 20 \\
\text { 南 } 20\end{array}$ & $\begin{array}{c}10 \\
5 \\
\end{array}$ & \\
\hline $3 / 3$ & $3 / 14$ & $\begin{array}{l}/ 3 \\
-8 \\
\end{array}$ & $\begin{array}{c}2 / 4 \\
-6\end{array}$ & & & & $8 / 4$ & 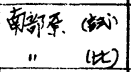 & $\begin{array}{l}3620 \\
667^{4}\end{array}$ & $\begin{array}{ll}\text { 比 } 12 \\
\text { 南 } 8\end{array}$ & $\begin{array}{l}15 \\
1.0\end{array}$ & \\
\hline $3 / 15$ & $216,9^{50}$ & $\begin{array}{c}2 / 5 \\
-6\end{array}$ & $\begin{array}{l}2 / 6 \\
-14\end{array}$ & & & & $2 / 164$ & $\begin{array}{c}\text { 清特䎦 (詨) } \\
11 \quad \text { (比) } \\
\end{array}$ & $\begin{array}{l}3298 \\
3288\end{array}$ & $\begin{array}{ll}\text { 些 } & 12 \\
\text { 南 } & 10\end{array}$ & $\begin{array}{l}10 \\
7\end{array}$ & \\
\hline 3/9 & 3/21 0.08 & $\begin{array}{l}3 / 9 \\
-8\end{array}$ & \begin{tabular}{|c|c|}
$3 / 20$ \\
-2
\end{tabular} & -6 & & & 8,2 & 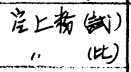 & - & $\begin{array}{ll}\text { 背 } & 20 \\
\text { 南 } & 20\end{array}$ & 8 & \\
\hline $3 / 21$ & $2 / 240.08$ & $\left.\right|_{-6} ^{3 / 2}$ & $\begin{array}{l}3 / 2 \\
-8\end{array}$ & \begin{tabular}{|c|}
$2 / 23$ \\
-8 \\
\end{tabular} & $\begin{array}{c}3 / 24 \\
-8\end{array}$ & & $8^{25}$ & 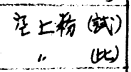 & 4083 & $\begin{array}{l}\text { 北 } 20 \\
\text { 南 } 20\end{array}$ & $\begin{array}{l}6 \\
2\end{array}$ & \\
\hline $3 / 26$ & $2 / 27 \quad 0.08$ & $\begin{array}{r}3 / 26 \\
-2\end{array}$ & $\begin{array}{l}3 / 29 \\
-1\end{array}$ & & & & $3 / 27{ }^{15}$ & 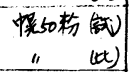 & 3695 & $\begin{array}{l}\text { 北 } 15 \\
\text { 南 } 12\end{array}$ & 2 & \\
\hline $2 / 27$ & $2 / 28 \quad 0.8$ & $2 / 27$ & $\frac{128}{2}$ & & & & $3 / 28$ & 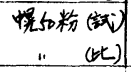 & $\begin{array}{l}5653 \\
8081\end{array}$ & $\begin{array}{ll}\text { 北 } 15 \\
\text { 南 } 12\end{array}$ & $\begin{array}{l}z \\
2\end{array}$ & \\
\hline
\end{tabular}


2.については現在のノズル挿入位置 (人力挿入の位置に適合 ) では, 下降後におけるノズル先端と貨車の底板に約 $200 \mathrm{~mm}$ の隌 間が生じ十分に底板を加熱することができず，ノズルを長くする ことにより凍結炭層問題も解消, 荷卸し作業の能率アップを計る ことが可能である。

3.についてはシリンダの昇降速度に多少のバラッキがあるが， 総体時間では初期の目的を達した。

4.については蒸気配管系統が多少複雑な機構のため, 人力用, ズルより多めの蒸気量が必要である。

$$
\text { 12. むすび }
$$

今回の実験を契機として今後の研究を進めるに当り, 次の項目 について改善が必要と考えられるので, 所見を述べむすびとさせ て頂く。
1. ノズル移動機構については今回の実験結果では異状は見受 けられなかつた。しかし当初想定された石炭の積載高さについては， さらに $150 \mathrm{~mm}$ 以上の貨車が入車するため移動時において,ズルガイ ドが石炭と干渉することが判明約 $200 \mathrm{~mm}$ のかさ上げが必要である。

2. 石炭の荷卸し作業を迅速且つ労働力を低減するためには貨 車の底板を十分加熱することが絶対条件と判明, 現在のノズル挿 入位置を商正と考えノズル長さを $400 \mathrm{~mm}$ 延長すべきである。

3. ディーゼル運転席の空の位置と保温蒸気受け樋の高さが同 一のため, 水蒸気が邪魔し運転士と操車係の確認が適格におこな われない。捅のかさ上げが必要である。

4. その他蒸気用電磁弁, 油圧シリンダ用流量調整弁の品質ア ップを計る。

以上申し述べた改善を推進し厳冬期に対応できるかどうかさら に研究を進めたい。

〔新技術紹介〕

（15）大型浮選機について

住友重機械エンバイロテック（株） 小川 七 郎

\section{1. まえがき}

産業界においては経済性を考慮した設備の大型化の傾向は, 依 然として続いており，ここに当社の親会社である米国Envirotech 社Wemco Divisionにおいて新たに開発された超大型浮選機 164 型と, 従来使用されてきた大型浮選機の比較検討結果を紹介する。

この超大型浮選機が出現した背景には, 世界的にみて, 金属, 非金属鉱山双方の傾向として, 低品位鉱石の出鉱量が次第に増大 し, それに伴つて関心が選鉱工場各機器の処理量のU P に向けら れたことにある。

現状では, 浮選機もこの処理量アップに対処するには数を増や すことしか一般には考えられないが，それでは床面積の増大，運 転動力費 U P , 配管の複雑化等いろいろ問題が生じる。そこで WEMCOでは, より大型の浮選機開発の必要性を認め, それに着 手, 完成し現在各所に納入しつつある。

\section{2. 浮 選 機}

第 1 図に浮選の基本的概念を示す。 2 つの流入路がこの図に示 されている。 A は空気流入路であり，Bはパルプ流入路である。

本機のような空気自吸式のものでは, 空気は上部セル表面より 入り，七ル底部より循環してきたパルブと気液混和域(1)で混る。 適正に設計された浮選機は十分な吸引空気量を有し, これをパル

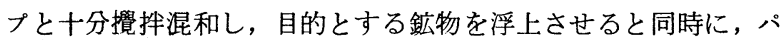
ルプ内の固体粒子を沈積させずに, 浮遊させる作業を行なう。

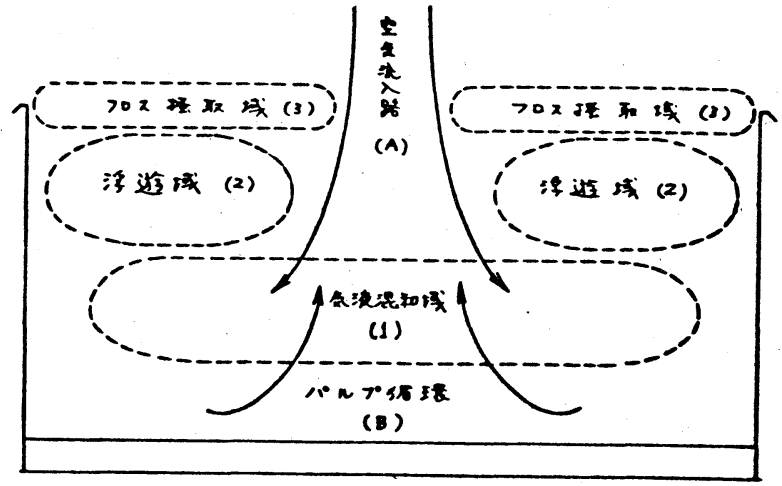

第1図 流動特性
この $2 つ の$ 条件を満足させるには，与えられたセル内において 吸引空気量とパルプ循環量だけではなく, 気液混合部での帯留時 間とセル底部からのパルプ上昇速度についても十分考慮されるべ きである。つまり浮遊域(2)に入る前に気泡と鉱物が接触する機会 を得るため, 適切な滞留時間が必要となる。また十分早いパルプ 上昇速度は底部に起りがちなサンディングの防止にも役立つこと になる。

パルブがセル底部に再循環して戻つて行く経路は，またフロス の分離作業の行なわれる浮遊域でもあるので, 気泡の浮揚効果を 増すためには，粒子の付着した気泡が破壊されずに上昇しうる程 度に静かで, 気泡分離に差支えない状態になつていることが大切 である。

気泡がセ儿表面に到達するにつれて破壊し, 濃縮され, 搔取域 (3)では除去容易なフロスにして取出される。

したがつて吸引空気量とパルプ循環量の微妙なバランスを取る ことが浮選操業上重要なことであり, 空気量が少なければ, 固体 粒子の浮上が十分に行なわれないし, また過度の空気量では浮遊 域で乱れを生じ，浮選効果を減らすことになる。

第 2 図に浮選機の概要を示す。本機は機外に空気導入システム を設置する必要のない空気自吸式である。口-タ(1)を回転させ， 隣接するパルプに渦を発生させ，口ータ中心部に 8〜 130 mm水柱 の真空が発生する。真空度は口ータの回転数, 浸漬量で決まる。

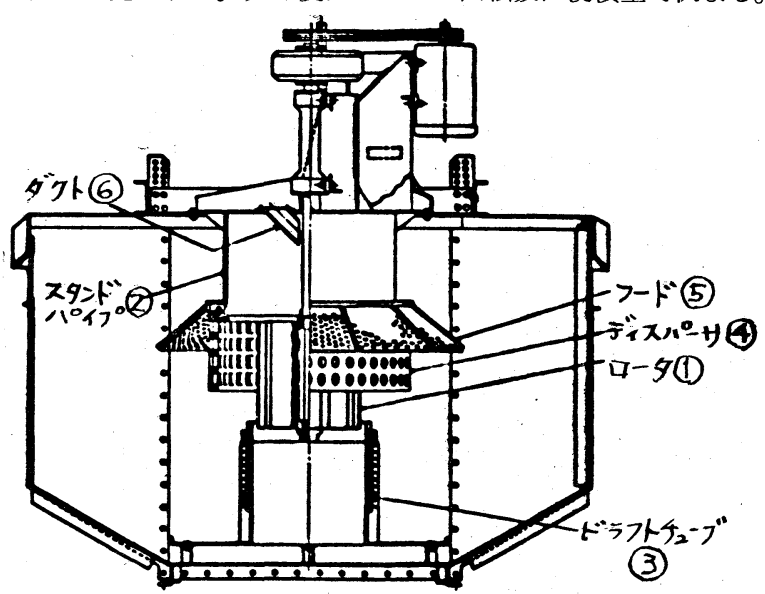

第 2 図断面図

日本鉱業会誌/95 $1099(' 79-9) 673<41>$ 